\title{
THE IMPACT OF TAX, EXCHANGE RATE, TUNNELING INCENTIVE, AND FIRM SIZE ON TRANSFER PRICING (Empirical Study of Manufacturing Companies Listed on the Indonesian Stock Exchange for Years 2014-2018)
}

\author{
Felicia Vanessa Wijaya, Luky Patricia Widianingsih \\ Universitas Ciputra Surabaya
}

\begin{abstract}
In the era of globalization, companies are developing into multinational companies that establish branches or subsidiaries in various countries. This globalization has given an impact to increase international transaction. These transactions could lead to transactions with related parties that shows an indication of transfer pricing. Along with the development of globalization, factors affecting transfer pricing are not only derived from taxes, but also from other factors. The purpose of this research is to examine the effect of tax, exchange rate, tunneling incentive, and firm size on transfer pricing. This research used secondary data in the form of annual reports published on the Indonesia Stock Exchange. Population of this research was manufacturing companies for years 2014-2018 and by purposive sampling method, a sample of 19 manufacturing companies was obtained. Analysis technique used on this research was a multiple linear regression using SPSS 23 application. The result shows that tax, tunneling incentive, firm size have significant effect on transfer pricing, while exchange rate does not take any effect on transfer pricing. Adjusted R2 determination coefficient of $32,8 \%$ shows transfer pricing is affected by tax, exchange rate, tunneling incentive, and firm size, while remaining 67,2\% is affected by other variables outside research model.
\end{abstract}

Keywords: transfer pricing; tax; exchange rate; tunneling incentive; firm size

\section{INTRODUCTION}

In the context of developing a company in the globalization era, companies establish or extend its branches, subsidiaries, and representative office in various countries which known as multinational companies. This development aims to

\footnotetext{
"Corresponding Author.

e-mail: feliciavanessa98@gmail.com
} 
strengthen the strategic alliance and grow export-import market of multinational companies' products in various countries (Pohan, 2014). Through this globalization has had an impact on increasing international transaction (cross border transaction). Sales transaction of goods and services to multinational companies could lead to special relationship transaction that risen the indication of transfer pricing practices. Transfer pricing is a company's policy in determining the price of interdivision or inter-company transactions under one parent company used to facilitate the company in adjusting internal prices for goods, services, and intangible assets traded so that prices created are not too high nor too low (Tiwa et al., 2017).

According to Deputy Minister of Finance Mardiasmono (2017), in theory practice of transfer pricing is allowed to be done by companies, but companies often use these practices without using the arm's length transaction standard. From the government side, misuse of transfer pricing can reduce and eliminate state's tax revenue. This is caused by multinational companies' tendency to replace their tax obligations from high tax countries to low tax countries. Deputy Minister of Finance Mardiasmono (2017) states that the implementation of transfer pricing by multinational companies is detrimental to the state since it diminishes corporate income tax revenue's basis, while $20 \%-30 \%$ of tax revenue in many countries originated from multinational corporation activities particularly manufacturing companies. According to Indonesian Deputy Minister of Taxation practice of transfer pricing gives significant effect to tax revenue and Indonesia has potential loss of 1.3 trillion rupiah ramifications of transfer pricing not based on arm's length transaction (DJP, 2011).

At the end of November 2005, Former Indonesian Minister of Finance Jusuf Anwar states that 750 companies had never paid taxes (Deputy Minister of Finance, 2017). The same issue has ever been stated by Directorate General of Taxation (DJP) that 2,000 multinational companies have not paid taxes in the past 10 years. This tax avoidance is done by transfer pricing and this become an evidence of transfer pricing as a classic issue that increase as time goes by. There are a few cases of transfer pricing existed in Indonesia's manufacturing companies over the past few years such as PT Coca Cola Indonesia (Djumena, 2014), PT Toyota Motor Manufacturing Indonesia, and PT Adaro Indonesia (Wareza, 2019). There are a few factors affecting transfer pricing, among others are: tax, 
Felicia Vanessa Wijaya, Luky Patricia Widianingsih / The Impact of Tax, Exchange Rate, Tunneling Incentive, and Firm Size on Transfer Pricing

exchange rate, tunneling incentive, and firm size. Those factors are going to be used as independent variable on this research.

Tax is one of the factors affecting transfer pricing on companies. The purpose of transfer pricing is to manipulate company's profits resulting in taxes and dividends paid by company is lessen and this shows that tax has a role in the decision of transfer pricing (Noviastika et al., 2016). Second factor that could affect transfer pricing is exchange rate's differences. Exchange rate fluctuation could affect practice of transfer pricing (Viviany, 2018). The third factor is tunneling incentive. Agency problems between majority and minority shareholders are the cause of tunneling (Refgia, 2017). The fourth factor is firm size. Large scale companies (with net assets above 10 billion rupiah) tend to be involved in more business and transactions then smaller companies (with net assets worth of 50-500 million), thus providing additional opportunities to significantly avoid taxes through transfer pricing.

Previous researches conducted by Noviastika (2016) resulted in a conclusion that tax and tunneling incentive have significant effect to transfer pricing, while good corporate governance has no effect to transfer pricing, those result were in line with researches conducted by Refgia (2017) resulted in a conclusion that tax, exchange rate, tunneling incentive have significant effect to transfer pricing, while mechanism bonus has no effect to transfer pricing. However, researchers conducted by Viviany (2018) resulted in a conclusion that tax and mechanism bonus have no effect against transfer pricing, while exchange rate and tunneling incentive have significant effect against transfer pricing. Researchers conducted by Cahyadi \& Noviari (2018) resulted in a conclusion that tax, profitability, and leverage have an influence in company's decision to transfer pricing, while exchange rate have no influence to transfer pricing. Variation of findings on past studies attract researcher to re-examine in order to find out whether tax, exchange rate, tunneling incentive, and firm size affect transfer pricing of manufacturing companies in Indonesia.

Reason of choosing manufacturing companies is transfer pricing often occurs in multinational companies on manufacturing sectors that have overseas subsidiaries, and also manufacturing sector is the largest contributor to national GDP and provide highest contribution as a tax depositor. Reason for the 2014-2018 research period is supported by the case of transfer pricing by Adaro Indonesia Ltd although the government has issued PMK 213 in 2016 (Wareza, 2019). 
Based on the introduction stated above, problem formulation can be obtained as follows: tax, exchange rate, tunneling incentive, and firm size affecting transfer pricing. The purpose of this study is to obtain empirical evidence of the effect of tax, exchange rate, tunneling incentive, and firm size on transfer pricing. Therefore, there will be four hypotheses in this research as follows:

H1: Tax affects transfer pricing

H2: Exchange rate affects transfer pricing

H3: Tunneling incentive affects transfer pricing

H4: Firm size affects transfer pricing.

\section{METHOD}

Variables related to this study can be stated as follows: transfer pricing as dependent variable $(\mathrm{Y})$, tax $(\mathrm{X} 1)$, exchange rate $(\mathrm{X} 2)$, tunneling incentive (X3), and firm size (X4) as independent variables. Systematically, research design in this study can be seen in Figure 1 (attached). This research used quantitative approach using secondary data with descriptive statistic models to analyze the causal relationship between variables and examine hypotheses that have been formulated (hypothesis testing). Secondary data sources in this study are annual reports of manufacturing companies listed on the Indonesia Stock Exchange in 2014-2018 period through www.idx.co.id or company's official website. Statistical analysis method is designed to examine independent variables that affect dependent variables on this study using pooled data. Measurement scale used in this study is ratio data.

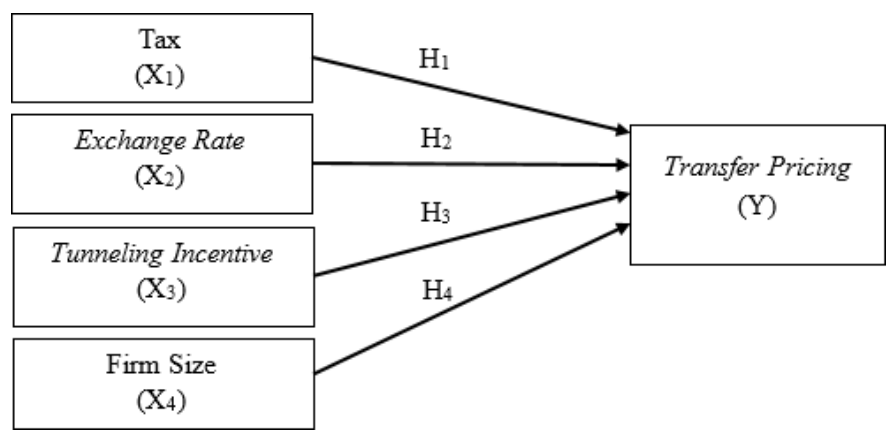

Figure 1 Research Design 


\section{Population and Sample}

Population in this study were manufacturing companies listed on the Indonesia Stock Exchange in 2014-2018 period with a total of 139 companies. Manufacturing companies include three industrial sectors, namely basic chemicals, various industries, and consumer goods industry. Sample is a collection of data that is parts of the population selected based on certain procedures in order to represent population (Purwanto \& Sulistyastuti, 2017). Sampling technique used in this study was purposive sampling, which is a sampling technique using specific criteria in connection with the data needed. Sample criteria used are:

1. Manufacturing companies are consecutively listed on the IDX in the 20142018 period.

2. Companies with capital ownership by foreign parties with a percentage of ownership equal to or more than $20 \%$ in accordance with PSAK 15 concerning investment in associated parties.

3. Company has a foreign exchange gain/(loss) data.

4. Company that discloses transactions with foreign companies that have a special relationship (UU No. 36 of 2008 concerning income tax).

5. Company that issues complete annual financial report.

6. Company did not experience losses during the observation period because company that suffered losses did not have tax obligations so tax reasons became irrelevant.

7. Companies were not delisted from IDX during the study period.

Based on those criteria, a sample of 19 companies was obtained with a total of 95 research data. Manufacturing companies were chosen because this company implements transfer pricing in corporate activities such as in the purchase of raw materials, production, and sales transactions through affiliated companies that have a special relationship, especially in multinational companies.

\section{Operational Definition and Variable Measurement Dependent Variable}

Transfer pricing is the price obtained in each product or service from one division that is transferred to another division in the same company or another company that has a special relationship. In this study, measurement of transfer pricing used can be seen in the following formula: 
Journal of Accounting, Entrepreneurship, and Financial Technology

Volume 01, Number 02, April 2020

$$
\text { Transfer Pricing }=\frac{\text { Related Party Receivables }}{\text { Total Receivables }} \times 100 \%
$$

\section{Independent Variable}

Tax is an amount of money paid as a mandatory contribution to the state owed by individuals or coercive entities under the Act. Tax variable is measured using the effective tax rate (ETR). ETR is measured using the following formula:

$$
\text { ETR (Effective Tax Rate) }=\frac{\text { Income Tax Expense }}{\text { Pretax Income }}
$$

Exchange rate is the price in exchange between two different currencies in circulation or it can be said the price of a foreign currency against domestic. Exchange rate is measured by the following formula:

$$
\text { Exchange Rate }=\frac{\text { Foreign Exchange Gain(Loss) }}{\text { Profit and (Loss) before Tax }}
$$

Tunneling incentive is an activity of transferring assets and outgoing profits of the company for the benefit of the controlling shareholders of the company. Tunneling incentive in this study is proxied by the percentage of foreign share ownership above $20 \%$ as the controlling shareholder.

Firm size is the scale of a company. Firm size in this study is measured by the natural logarithm of total assets which can be formulated as follows:

\section{SIZE: $\log _{n}$ Total Company Asset}

\section{Data Analysis Method}

Descriptive statistical analysis is used to provide data overview that can be seen from minimum, maximum, mean, and standard deviation values. Data examined are tax, exchange rate, tunneling incentive, firm size, and transfer pricing. Before conducting multiple linear regression analysis, data are tested first using the classical assumption test. Classical assumption tests performed are test of normality, multicollinearity, heteroscedasticity, and autocorrelation. F-statistic test (simultaneous test) and coefficient of determination (adjusted R2) test is used 
to examine whether the research model is accepted. Hypothesis testing is done in the form of $\mathrm{t}$ - test (partial test) with the regression equation as follows: $\mathrm{Y}=\alpha+\beta 1(\mathrm{ETR})+\beta 2$ (exchange rate) $+\beta 3$ (tunneling incentive) $+\beta 4$ (Size) $+\varepsilon$

\section{RESULTS}

Number of manufacturing companies listed on the IDX in the 2014-2018 period used as samples are 19 companies and resulted in a total of 95 data will be used in the study. Table 1 shows the data research sampling. Out of the 95data selected as the research samples, there are data that have abnormally distributed. Hence, there were a reduction in data of 29 observational data which makes a total of 66 research data that will be used in this study. The list of manufacturing companies sampled in this study can be seen from Table 2 .

\section{Tabel 1 Research Data}

\begin{tabular}{clc}
\hline No. & \multicolumn{1}{c}{ Criteria } & Total \\
\hline 1 & $\begin{array}{l}\text { Manufacturing companies that published the } 2014-2018 \text { financial } \\
\text { statements }\end{array}$ & 695 \\
2 & Manufacturing companies without foreign ownership $\geq 20 \%$ & -375 \\
3 & Manufacturing companies that do not disclose profit(loss) of foreign & -45 \\
4 & exchange differences & -105 \\
5 & Manufacturing companies that suffered losses during the study period & Manufacturing companies that do not disclose transactions with related \\
6 & Manufacturing companies were delisted during the study period & -50 \\
Total Research Data & -25 \\
\hline
\end{tabular}

Table 2 List of Sample of Manufacturing Companies Participated in this Research

\begin{tabular}{clc}
\hline No. & \multicolumn{1}{c}{ Company Name } & $\begin{array}{c}\text { Meet } \\
\text { the Criteria }\end{array}$ \\
\hline 1 & PT Indocement Tunggal Prakasa Tbk. & $\sqrt{ }$ \\
2 & PT Arwana Citramulia Tbk. & $\sqrt{ }$ \\
3 & PT Surya Toto Indonesia Tbk. & $\sqrt{ }$ \\
4 & PT Lion Metal Works Tbk. & $\sqrt{ }$ \\
5 & PT Pelangi Indah Canindo Tbk. & $\sqrt{ }$ \\
6 & PT Charoen Pokphand Indonesia Tbk. & $\sqrt{ }$ \\
7 & PT Japfa Comfeed Indonesia Tbk. & $\sqrt{ }$ \\
8 & PT Astra Internasional Tbk. & $\sqrt{ }$
\end{tabular}


9 PT Indo Kordsa Tbk.

10 PT Sumi Indo Kabel Tbk.

11 PT Indofood Sukses Makmur Tbk.

12 PT Nippon Indosari Corpindo Tbk.

13 PT Sekar Bumi Tbk.

14 PT Sekar Laut Tbk.

15 PT Darya-Varia Laboratoria Tbk.

16 PT Merck Tbk.

17 PT Taisho Pharmaceutical Indonesia Tbk.

18 PT Mandom Indonesia Tbk.

19 PT Unilever Indonesia Tbk.

\section{Descriptive Statistic of Research Variables}

Descriptive statistic from the research data is stated in Table 3, where in total there are 66 total observations. Average tax value of 66 observational data illustrated by ETR shows a result of 0.2748 with a standard deviation of 0.12674 which indicates that in general manufacturing companies have a high level of tax aggressiveness to reduce the effective tax rate. The lowest value of tax is 0.0100 which is owned by PT Merck Tbk. in 2018 and the highest value is 0.6300 owned by PT Japfa Comfeed Indonesia Tbk. in 2017. Average exchange rate value with a standard deviation of 0.04081 shows a value of 0.9985 which indicates that manufacturing companies have a tendency to use foreign currencies in operational and financial activities. The lowest value of exchange rate is 0.8700 owned by PT Japfa Comfeed Tbk. in 2018 and the highest value is at 1.1000 owned by PT Sumi Indo Kabel Tbk. in 2018.

Table 3 Descriptive Statistic of Research Variables

\begin{tabular}{lccccc}
\hline \multicolumn{1}{c}{ Variable } & N & Minimum & Maximum & Mean & Std. Deviation \\
\hline Tax & 66 &, 0100 &, 6300 &, 2748 &, 12674 \\
Exchange Rate & 66 &, 8700 & 1,1000 &, 9985 &, 04081 \\
Tunneling Incentive & 66 &, 2100 &, 9300 &, 60000 &, 22791 \\
Firm Size & 66 & 26,8500 & 33,4700 & 29,0285 & 1,8251 \\
Transfer Pricing & 66 &, 0004 &, 9600 &, 2679 &, 3210 \\
Valid N (listwise) & 66 & & & & \\
\hline
\end{tabular}

The average value of tunneling incentive indicates a value of 0.60000 with a standard deviation value of 0.22791 which indicates that the ownership 
structure of a company tends to be concentrated in a small number of parties. Tunneling incentive has the lowest value of 0.2100 owned by PT Nippon Indosari Corpindo Tbk. in 2017-2018. The highest value is at 0.9300 which is owned by PT Darya-Varia Laboratoria Tbk. in 2014-2016. Average value of firm size is 29.0285 with a standard deviation value of 1.8251 which shows that in general the amount of company assets reflected in the total assets can be used to support operational activities. Lowest value of 26.8500 owned by PT Taisho Pharmaceutical Indonesia Tbk. in 2014 and the highest value is 33.4700 owned by PT Astra International Tbk. in 2018. Average value of transfer pricing shows a number of 0.2679 with a standard deviation of 0.3210 which indicates that manufacturing companies tend to make transactions with affiliated companies that have a special relationship. Dependent variable transfer pricing has the lowest value of 0.0004 owned by PT Merck Tbk. in 2015 and highest value of 0.9600 owned by PT Arwana Citramulia in 2015.

\section{Data Quality Test}

Table 4 Normality Test Using Kolmogorov-Smirnov

\begin{tabular}{cccc}
\hline & $\begin{array}{c}\text { Asymp. Sig. } \\
(2 \text {-tailed) }\end{array}$ & $\begin{array}{c}\text { Criteria for Normal } \\
\text { Distributed Data }\end{array}$ & Result \\
\hline Unstandarized Residual & 0,197 & Sig $>0,05$ & Normal \\
\hline
\end{tabular}

Table 5 Multicollinearity Test Using Tolerance Value and VIF

\begin{tabular}{lccc}
\hline \multicolumn{1}{c}{ Variable } & $\begin{array}{c}\text { Tolerance } \\
>0,10\end{array}$ & VIF $<10$ & \multicolumn{1}{c}{ Result } \\
\hline Tax & 0,921 & 1,086 & There is no multicollinearity \\
Exchange Rate & 0,918 & 1,090 & There is no multicollinearity \\
Tunneling Incentive & 0,928 & 1,078 & There is no multicollinearity \\
Firm Size & 0,856 & 1,168 & There is no multicollinearity \\
\hline
\end{tabular}

Table 6 Heteroscedasticities Test Using Run Test

\begin{tabular}{lcc}
\hline \multicolumn{1}{c}{ Variable } & $\begin{array}{c}\text { Asymp. Sig. (2-tailed) } \\
>\mathbf{0 , 0 5}\end{array}$ & \multicolumn{1}{c}{ Result } \\
\hline Tax & 0,207 & There is no heteroscedasticity \\
Exchange Rate & 0,944 & There is no heteroscedasticity \\
Tunneling Incentive & 0,776 & There is no heteroscedasticity \\
Firm Size & 0,557 & There is no heteroscedasticity \\
\hline
\end{tabular}


Journal of Accounting, Entrepreneurship, and Financial Technology

Volume 01, Number 02, April 2020

Table 7 Autocorrelation Test Using Durbin-Watson Test

\begin{tabular}{lcccl}
\hline \multicolumn{1}{c}{ Model } & Du & Dw & 4-Du & \multicolumn{1}{c}{ Result } \\
\hline $\begin{array}{l}\text { Regression (dependent: } \\
\text { transfer pricing) }\end{array}$ & 1,7311 & 2,257 & 2,2669 & $\begin{array}{l}\text { There is no } \\
\text { autocorrelation }\end{array}$ \\
\hline
\end{tabular}

The first classic assumption test is the normality test. Normality test aims to determine whether data has been normally distributed so that it can be used as research observations (Santoso, 2018). Normality test conducted using Kolmogorov-Smirnov test. Result shown in Table 4 shows that data has been normally distributed with a significance value of $0.197>0.005$. Secondly, a multicollinearity test was performed. Multicollinearity testing aims to determine whether or not there is a relationship between one or more independent variables with other independent variables (Purwanto \& Sulistyastuti, 2017). Multicollinearity test results in Table 5 show that the data have a tolerance value $>0.10$ and VIF $<10$, therefore it can be concluded that there was no multicollinearity problem.

Thirdly, a heteroscedasticity test was performed. Heteroscedasticity test aims to detect the presence or absence of variable variance that is not constant or the difference of variable variance in the regression from one observation to another (Purwanto \& Sulistyastuti, 2017). The test is carried out using the Spearman's Rho test with the basis of decision making if the value is significant $>0.05$. Based on Table 6 , it can be concluded that there was no heteroscedasticity in the research model. Lastly, autocorrelation test was performed. The autocorrelation test aims to detect whether the confounding variable at $\mathrm{t}$-time correlates or not with other confounding variables (Purwanto \& Sulistyastuti, 2017). Autocorrelation test results in Table 7 shows that value of $\mathrm{du}<\mathrm{d}<4$-du which is $1.7311<$ $2.257<2.2669$. Hence, it can be concluded there was no autocorrelation in this research model.

\section{Multiple Linear Regression Method}

Based on the multiple linear regression method that has been done shown in Table 8, the multiple linear regression equation in this study can be arranged as follows:

Transfer Pricing $=2,274-0,541 \mathrm{X} 1+0,622 \mathrm{X} 2-0,587 \mathrm{X} 3-0,073 \mathrm{X} 4$ 
Table 8 Multiple Linear Regression

\begin{tabular}{lc}
\hline \multicolumn{1}{c}{ Model } & Unstandardized Coefficients \\
& B \\
\hline Constant & 2,274 \\
Tax (X1) & $-0,541$ \\
Exchange Rate (X2) & 0,622 \\
Tunneling Incentive (X3) & $-0,587$ \\
Firm Size (X4) & $-0,073$ \\
\hline
\end{tabular}

\section{Model Feasibility Test}

Table 9 Result of F-Statistic test

\begin{tabular}{lcc}
\hline \multicolumn{1}{c}{ Model } & F & Sig. \\
\hline $\begin{array}{l}\text { Regression (dependent: transfer } \\
\text { pricing) }\end{array}$ & 8,937 &, 000 \\
\hline
\end{tabular}

Table 10 Result of Determination Coefficient (Adjusted $\mathbf{R}^{2}$ )

\begin{tabular}{cc}
\hline Model & Adjusted R Square \\
\hline Regression (dependent: transfer pricing) & 0,328 \\
\hline
\end{tabular}

According to Table 9, result of F-statistic test shows significance value less than 0.05 , which is equal to 0.000 . From the significance value, it is known that independent variables in this study has a simultaneous effect on transfer pricing, therefore the research model is feasible to be continued further. Meanwhile, the result of Coefficient of Determination test (Adjusted R2) resulted with a value of 0.328 and is shown in Table 10. This result means that the independent variables used in this study are able to explain the dependent variable by $32.8 \%$, while the remaining $67.2 \%$ is explained by other independent variables outside this study.

Table 11 Result of $\mathrm{t}$-Test (Partial Test)

\begin{tabular}{lcc}
\hline \multicolumn{1}{c}{ Model } & $\mathbf{t}$ & Sig. \\
\hline Constant & 2,106 &, 039 \\
Tax (X1) & $-2,017$ &, 048 \\
Exchange Rate (X2) &, 745 &, 459 \\
Tunneling Incentive (X3) & $-3,948$ &, 000 \\
Firm Size (X4) & $-3,790$ &, 000 \\
\hline
\end{tabular}


According to Table 11, it can be seen that tax has a significance value of $0.048<0.005$, tunneling incentive has significance value of $0.000<0.05$, and firm size has significance value of $0.000<0.005$. Those results shows that tax, tunneling incentive, and firm size have significant effect on transfer pricing, which means hypotheses one, three, and four of this study were accepted. Meanwhile, exchange rate shows significance value of $0.459>0.005$ which means exchange rate has no effect on transfer pricing and it can be said that hypotheses two were rejected.

\section{DISCUSSION}

The research results showed that tax had a significant effect on transfer pricing, meaning that tax had a strong role for manufacturing companies to carry out practice of transfer pricing. High tax rates will encourage companies to carry out tax management through transfer pricing. Those was done by moving company's tax obligations from countries with high tax rates to countries with low tax rates through affiliated companies abroad (Refgia, 2017). This finding supports the legitimacy and agency theory. According to agency theory by Jensen \& Meckling (1976), company management will try to maximize profits by doing tax management so that the tax burden to be paid is lessen. Based on the result and argument, it can be concluded that tax's factor gives contribution to company's decision to carry out transfer pricing in order to reduce taxes that must be paid. The result of this study contradicts Viviany's (2018) research, but is in line with research conducted by Noviastika F (2016); Refgia (2017) which have proven that tax has a significant effect on transfer pricing.

The results showed that exchange rate had no effect on transfer pricing. Doupnik \& Perera (2015) state that fluctuations or changes in foreign exchange rates do not always go as expected by the company. The existence of uncertainty about changes in foreign exchange rates has an impact on the company's financial decision making which can make the company make transactions related to the exchange rate with caution or as minimum as possible. Hypotheses test results indicated that fluctuations in foreign exchange rates do not provide a role or incentive for manufacturing companies to practice transfer pricing. 
Felicia Vanessa Wijaya, Luky Patricia Widianingsih / The Impact of Tax, Exchange Rate, Tunneling Incentive, and Firm Size on Transfer Pricing

Manufacturing companies tend to be able to use differences in foreign exchange rates appropriately such as conducting transactions when the exchange rate is strong so that there is no need to practice transfer pricing affected by the exchange rate. This finding supports the legitimacy and agency theory which shows that management will make every effort to avoid the risk of loss on foreign exchange differences to create maximum company performance. Based on the explanation, it can be concluded that the exchange rate does not influence the company's decision to transfer pricing. The result of this study contradicts Viviany's (2018), but is supported by the research of Cahyadi \& Noviari (2018) which proves that exchange rates affect transfer pricing.

T-Statistic test results indicate tunneling incentive significantly influence transfer pricing. Tunneling incentive that was measured using a proxy of share ownership by foreign entities as a controlling party shows that the presence of a controlling shareholder in a company affects the company's decision to transfer pricing. The result showed that manufacturing companies tend to do tunneling incentive through transfer pricing with related parties. This practice is driven by the behavior of the majority shareholders who want to have greater profits. The tendency to carry out these practices can be detrimental to subsidiary companies or minority shareholders. This can occur when the subsidiary company sells inventory to the parent company at a price far below the market price, thereby making the subsidiary company experience losses and only benefit the parent company. This finding supports the legitimacy and agency theory which shows that delegation of authority from the owner of the company to the manager makes the manager must act in accordance with the wishes of the owner aiming for maximum benefit possible. Based on the hypothesis testing that has been done and the explanation stated, it can be concluded that tunneling incentive influence the company's decision in the practice of transfer pricing. This finding is in line with research results by Noviastika F (2016); Refgia (2017); Viviany (2018) which have proved tunneling incentive has a significant effect on transfer pricing.

T-test results show that firm size has a significant effect on transfer pricing. The company's ability to carry out its operational activities is reflected in the total assets owned by the company (Refgia, 2017). The greater the total assets owned by the company, the greater the size of the company. A relatively larger 
company will have a tendency to show satisfactory performance that is reflected in high profits by transfer pricing. Whereas relatively smaller companies will tend to do transfer pricing to reduce the tax burden that must be paid so that the profits obtained are greater and can be used as operational or financing to develop their company. This finding supports the legitimacy and agency theory which shows that the greater the company will make the principal delegate its authority to the professional workforce in managing the company in order to obtain maximum benefits. Companies will tend to do transfer pricing as a tool to minimize tax burden and maximize profits on both companies that are classified as large or small. Based on the explanation and results of the hypothesis test, it can be concluded that firm size has an influence on the company's decision to practice transfer pricing. This result contradicts Refgia's (2017), but supported by Azzahra's research (2019) which proves that firm size has a significant effect on transfer pricing.

\section{Conclusion}

This study can conclude that tax, tunneling incentive, and firm size are significantly influence transfer pricing of manufacturing companies listed on the IDX in 2014-2018. While the exchange rate has no effect on transfer pricing of manufacturing companies listed on the IDX in 2014-2018. From the results of this study, it was found that differences in tax rates encourage companies to do transfer pricing, while the exchange rate does not. Tunneling incentive also encourage manufacturing companies to move assets or profits through transfer pricing. Firm size which shown by small or large scale companies tend to do transfer pricing to show good company's performance by managing tax and transaction with related parties.

\section{Limitations and Suggestions}

This study has several limitations which are explained as follows:

1. There is a reduction in data or outliers by 29 observational data because the initial observation data used by researchers is not normally distributed. Hence, the number of initial observation data used was changed from 95 to 66 observation data after an outlier. 
2. The four independent variables of this study (tax, exchange rate, tunneling incentive, and firm size) only have an effect of $32.8 \%$ on transfer pricing. While the remaining $67.2 \%$ is the influence of other variables outside the research model that cannot be explained in this study.

Researchers also provide some suggestions that can be implemented such as: future studies can use other variables that might affect transfer pricing (e.g.: leverage, bonus mechanism, multinationalism, debt covenant, foreign ownership). Subsequent research should also use companies from different industries or sectors of the company and use a longer time span so that it can provide results that can reflect conditions in the company sector other than manufacturing in Indonesia. By the proven result of tax, tunneling incentive and firm size as an encouragement for companies to conduct transfer pricing, the government can improve regulations, tighten supervision of transfer pricing, and minimize loophole to reduce transfer pricing practices that are not in accordance with arm's length transaction that have been set.

\section{REFERENCES}

Ariyanti, F. (2016). 2.000 Perusahaan Asing Gelapkan Pajak Selama 10 Tahun. Retrieved on February 19, 2019, from https://www.liputan6.com/bisnis/ $\mathrm{read} / 2469089 / 2000$-perusahaan-asing-gelapkan- pajak-selama-10-tahun.

Azzahra, K. (2019). Analisis Pengaruh Ukuran Perusahaan, Kepemilikan Asing, dan Tunneling Incentive Terhadap Transfer Pricing. Unes Journal of Economics Scienties, 2(1), 30-44.

Cahyadi \& Noviari. (2019). Pengaruh Pajak, Exchange Rate, Profitabilitas, dan Leverage Pada Keputusan Melakukan Transfer Pricing. E-Journal Akuntansi Universitas Udayana, 24(2), 1441-1473.

Direktur Jenderal Pajak. (2011). Peraturan Direktur Jenderal Pajak Nomor PER32/PJ./2011 tentang Penerapan Prinsip Kewajaran dan Kelaziman Usaha dalam Transaksi antara Wajib Pajak dengan Pihak yang Mempunyai Hubungan Istimewa. Jakarta, Indonesia: Direktur Jenderal Pajak. 
Djumena, E. (2014). Coca-Cola Diduga Akali Setoran Pajak. Retrieved on February 19, 2019, from https://ekonomi.kompas.com/read/2014/06/13/ 1135319/Coca-Cola.Diduga.Akali.Setoran.Pajak.

Doupnik, T. \& Perera, H. (2015). International Accounting Fourth Edition. New York: McGraw-Hill Education.

Ikatan Akuntan Indonesia. (2015). Pernyataan Standar Akuntansi Keuangan (PSAK) No. 7 (Penyesuaian 2015) tentang Pihak-Pihak yang Mempunyai Hubungan Istimewa. Jakarta, Indonesia: IAI.

Jensen, M.C. \& Meckling, W.H. (1976). Theory of the Firm: Managerial Behavior, Agency Cost, and Ownership Structure. Journal of Financial Economics, 3(4), 305-360.

Deputy Minister of Finance. (2017).Peraturan Menteri Keuangan Nomor: 213/ PMK.03/2016 tentang Jenis Dokumen dan/atau Informasi Tambahan yang Wajib Disimpan oleh Wajib Pajak yang Melakukan Transaksi dengan Para Pihak yang Mempunyai Hubungan Istimewa, dan Tata Cara Pengelolaannya. Jakarta, Indonesia: Menteri Keuangan Republik Indonesia.

Noviastika F., D., Mayowan, Y., \& Karjo, S. (2016). Pengaruh Pajak, Tunneling Incentive dan Good Corporate Governance (GCG) terhadap Indikasi Melakukan Transfer Pricing Pada Perusahaan Manufaktur yang Terdaftar di Bursa Efek Indonesia (Studi Pada Bursa Efek yang Berkaitan dengan Perusahaan Asing). Jurnal Perpajakan (JEJAK), 8(1), 1-9.

Pemerintah Indonesia. (2008). Undang-Undang Republik Indonesia Nomor 36 Tahun 2008 tentang Pendapatan Pajak. Lembaran Negara RI Tahun 2007, No. 28. Jakarta, Indonesia: Sekretariat Negara.

Pohan, C. (2014). Manajemen Perpajakan: Strategi Perencanaan Pajak dan Bisnis (Edisi Revisi). Jakarta, Indonesia: PT Gramedia Pustaka Utama.

Purwanto, E. A. \& Sulistyastuti, D. R. (2017). Metode Penelitian Kuantitatif: untuk Administrasi Publik dan Masalah-Masalah Sosial (Edisi Kedua). Yogyakarta, Indonesia: Gava Media.

Refgia, T. (2017). Pengaruh Pajak, Mekanisme Bonus, Ukuran Perusahaan, Kepemilikan Asing, dan Tunneling Incentive Terhadap Transfer Pricing (Perusahaan Sektor Industri Dasar dan Kimia yang Listing di BEI Tahun 2011-2014). JOM FEKON, 4(1), 543-555. 
Santoso, S. (2018). Menguasai Statistik dengan SPSS 25. Jakarta, Indonesia: PT Elex Media Komputindo.

Tiwa, Saerang. \& Tirayoh. (2017). Pengaruh Pajak dan Kepemilikan Asing Terhadap Transfer Pricing Pada Perusahaan Manufaktur. Jurnal EMBA, 5(2), 2666-2675.

Viviany. (2018). Pengaruh Tarif Pajak, Tunneling Incentive, Mekanisme Bonus, dan Exchange Rate Terhadap Transfer Pricing (Studi Empiris Pada Perusahaan Manufaktur yang Terdaftar di Bursa Efek Indonesia Tahun 2013-2016). JOM FEB, 1(1), 1-15.

Wareza, M. (2019). Disebut Terlibat Transfer Pricing Adaro, Siapa Coaltrade? Retrieved on September 23, 2019, from https://www.cnbcindonesia.com/ news/20190704205102-4-82830/disebut-terlibat-transfer-pricing-adarosiapa-coaltrade. 
Journal of Accounting, Entrepreneurship, and Financial Technology

Volume 01, Number 02, April 2020 